\title{
The iconosphere of contemporary terrorism in the perspective of visual arts
}

\begin{abstract}
The perspective on terrorism adopted in the paper Visual Culture in the Age of Terrorism is closest to visual studies in the field of cultural studies. Discussions on the topic of visual studies over the last decades have so far resulted in numerous publications and commentaries, but one can have the impression that more than enough they constituted meta-narratives describing research methods rather than implementations of these methods. Meanwhile, research methods appear to be very adequate tools of cultural analysis, in which the component of visual communication is gaining significance. After WWII, it is terrorism and its iconosphere that have prov`en to be the most distinct examples of visual communication.

The paper's aim is to present the images whose source or topic is terrorism and in particular it is about the cultural regimes of production and decoding of these images. The images are culturally framed in line with the iconological tradition, and so the way in which they are interpreted, assigned meaning and studied according to their impact on the field requires some sensitization to cultural contexts, constant consultations between various practices, discourses and disciplines, looking straight ahead and sideways, and sometimes from different perspectives simultaneously.
\end{abstract}

Keywords: terrorism, visual culture, art, iconology, iconosphere

y perspective on terrorism is closest to visual studies in the field of cultural
studies. Discussions on the topic of visual studies over the last decades have so far resulted in numerous publications and commentaries, but one can have the 
impression that more than enough they constituted meta-narratives describing research methods rather than implementations of these methods. Meanwhile, research methods appear to be very adequate tools of cultural analysis, in which the component of visual communication is gaining significance. In recent years, it is terrorism and its iconosphere that have proven to be the most distinct examples of visual communication.

The paper's aim is to present the images whose source or topic is terrorism (broadly understood, without ethic judgments), and in particular it is about the cultural regimes of production and decoding of these images ${ }^{1}$. The images are culturally framed in line with the iconological tradition, and so the way in which they are interpreted, assigned meaning and studied according to their impact on the field requires some sensitization to cultural contexts, constant consultations between various practices, discourses and disciplines, looking straight ahead and sideways, and sometimes from different perspectives simultaneously. Therefore, it is so very important to look at the images that are produced, evoked, fought and appropriated by terrorism, and at the same time to capture the cultural contexts accompanying these processes.

The notion of terrorism as such still remains undefined - it embraces so many discourses that any attempt at a comprehensive definition seems pointless - it is difficult to capture its religious, political or economic determinants all at once. The fact is that they all are inseparably connected but, paradoxically, they involve different interpretative perspectives and have non-convergent points of gravity. I therefore abandon the ambition of theoretical generalization on the notion of terrorism (or worse, its universal interpretation) in favor of particular iconological inquiries. Undoubtedly, fear is a terrorist tool, and a spectacular act of violence is necessary for its effective inducement. The immortalization of terrorist acts or revolutionaries and anarchists was characteristic of pictorial art already in the 18th or 19th centuries. Contemporary visual culture is not so much a pioneer in this respect, but rather it offers a much wider spectrum of imaging tools. Today, we can witness countless afterimages of terrorism, very graphic messages - how they last, pass away, suddenly come to life again - together with the temporary and long-term effects they bring about. Some images provoke new images, for example Danish cartoons of Mohammed (2005), while others provoke real violence and killing, such as the attack on the editorial office of Charlie Hebdo (2015).

My main research ambition is to become familiarized with selected cultural practices connected with the production, distribution and understanding of images whose main source (or point of reference) is terrorism in its various incarnations. On this occasion, a number of key questions emerged, which needed to be resolved: Were there any changes in the strategies and tactics used by terrorists in

${ }^{1}$ I discuss this issue in a much more detail in the book: Kultura wizualna $w$ dobie terroryzmu, Wydawnictwo Naukowe Wydziału Nauk Społecznych UAM, Poznań 2018. 
visual communication in recent decades? What were the cultural consequences of this communication? What did the policies of illustrating terrorism in the media and the artistic culture (amateur, professional) look like? What is the role of art in co-creating the archive of terrorism?

The first question determined in a significant way the structure of this paper, which is composed of parts addressing some visual aspects of terrorism: the left-anarchist Rote Armee Fraktion, the national liberation (examples of Northern Ireland and Palestine), and the religious-fundamentalist aspect, with examples of Al-Qaeda and the so-called Islamic State (ISIS). This classification, apart from showing the diversity of cultural contexts, helps us gain insight into the changes in visual communication shared by individual terrorist groups, and learn more about different ways in which the world of artistic culture reacted. Art as a very sensitive "barometer" of cultural phenomena was often able to provide more in-depth and nuanced diagnoses than the media or state authorities. Artists (usually) are exempt from political correctness, in other words they act and create, penetrating discourses, which enables them to effectively sensitize their audiences to cultural aporias, paradoxes and traps. Their strategy is fearless commitment to the cause and adopting a critical standpoint on things, which makes them immune to accusations of political bias. Among such and other unfavorable opinions on art and artists there was one stating that art is somewhat envious of the effectiveness of terrorism in influencing the "audience," therefore the art world tackles the theme of terrorism. ${ }^{2}$ At the other end of the spectrum, researchers trying to define terrorism often talk about it in purely aesthetic categories - in terms of a spectacle, a performance or the sublime (in the Kantian sense). One way or another, a dangerous relationship between the artist and the terrorist has emerged on several levels, the(ir) common ground being a desire to evoke emotions and provoke specific behaviours. Many artists were accused of glorifying terrorists, preying on social and individual traumas, or sometimes the accusations were more banal - sensationalism.

Is it possible then, in the polyphony of artistic culture, to search for the meanings of the difficult concept of terrorism? The examples of artistic commentaries on terrorism and terrorist attacks collected in this article did not always meet with social understanding; even worse - they were labeled as inappropriate or inadequate in this context. When artists occupied themselves with a hot, current topic, they were often accused of sympathizing with the terrorists by "honouring" the terrorists' destructive activities with their art. This led to controversies, which obviously resulted in revoking exhibitions or partial interventions by censors. Somehow, our society has developed the conviction that it is only the media and

${ }^{2}$ In an atmosphere where the flag is freedom, and not just its symbol, some artists must feel guilty that they share with terrorists a zealous desire to change the world - as James Hannaham put it in his comments on Laurie Anderson performance Happiness; J. Hannaham, Disaster areas, https://www.villagevoice.com/2002/07/30/disaster-areas/ [access: 22.11.2020]. 


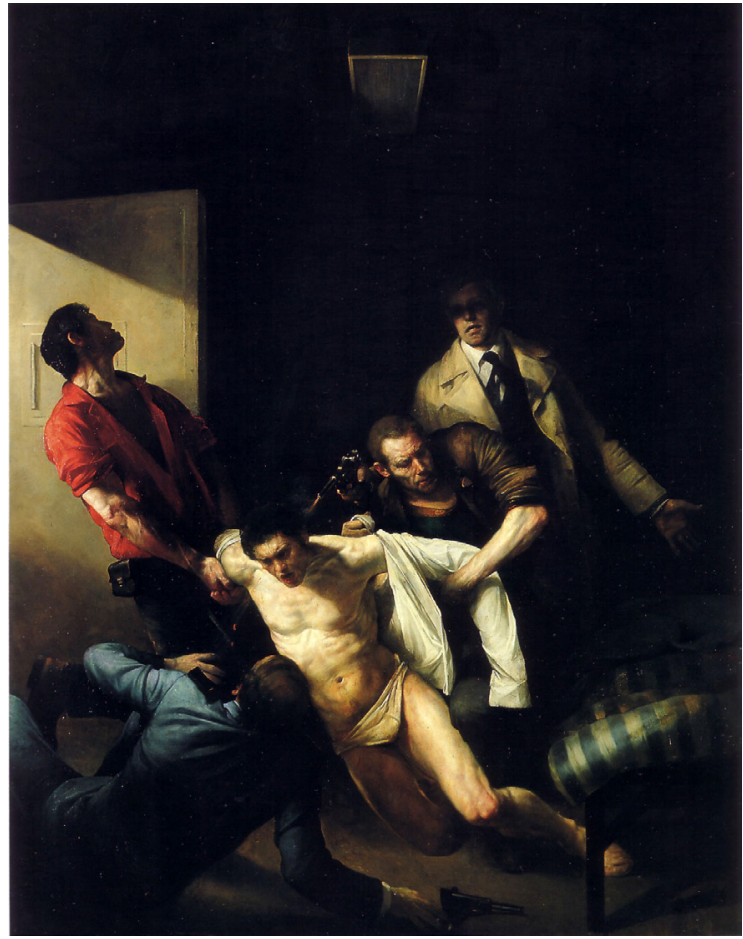

Picture 1. Odd Nerdrum, Mordet pa Andreas Baader (The Murder of Andreas Baader), $1977 / 78$

Source: https://thornews.com/2012/11/30/odd-nerdrum-the-odd-master-of-kitsch/odd-nerdrumthe-murder-of-andreas-baader-1977/ [access: 22.11.2020].

the terrorists that have the monopoly on "symbolic production" in this area. It was especially visible during the massive campaign by the West German government against the terrorists from RAF and their numerous supporters. The stake in this uneven game was cultural memory, which the German state was trying to propagate precisely through the media and with immediate effect. This top-down perspective was disturbed by the contemporary cinema and art, naturally with various effects.

Almost immediately after the death of Andreas Baader, the Norwegian artist Odd Nerdrum painted a monumental oil painting Mordet pa Andreas Baader. The scene immortalized on the canvas shows the dark interior of a prison cell, a half-naked victim and four attackers. Although the picture is painted very skillfully in a convention similar to Caravaggio's Crucifixion of St. Peter (1601), the author intended it to be kitsch. The matter seems more complex, however, as Nerdrum admits to his then anarchist views and his fascination with the Baader-Meinhof group. Ostentatiously, he decided to enter the mood of conspiracy theories ques- 


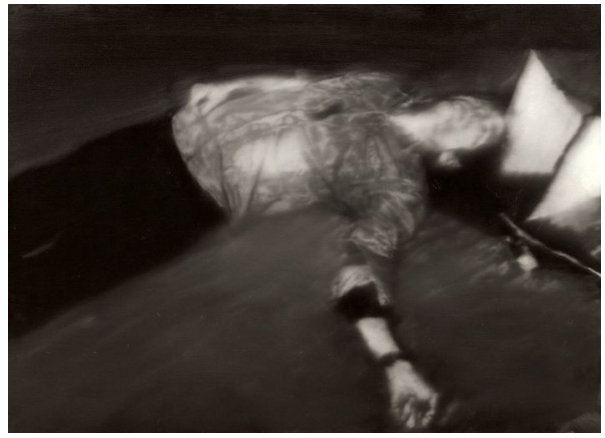

Picture 2. Gerhard Richter, Erschossener 1, Man Shot Down 1, from the series 18 Oktober 1977, 1988

Source: http://www.tate.org.uk/context-comment/articles/inescapable-truths [access:22.11.2020].

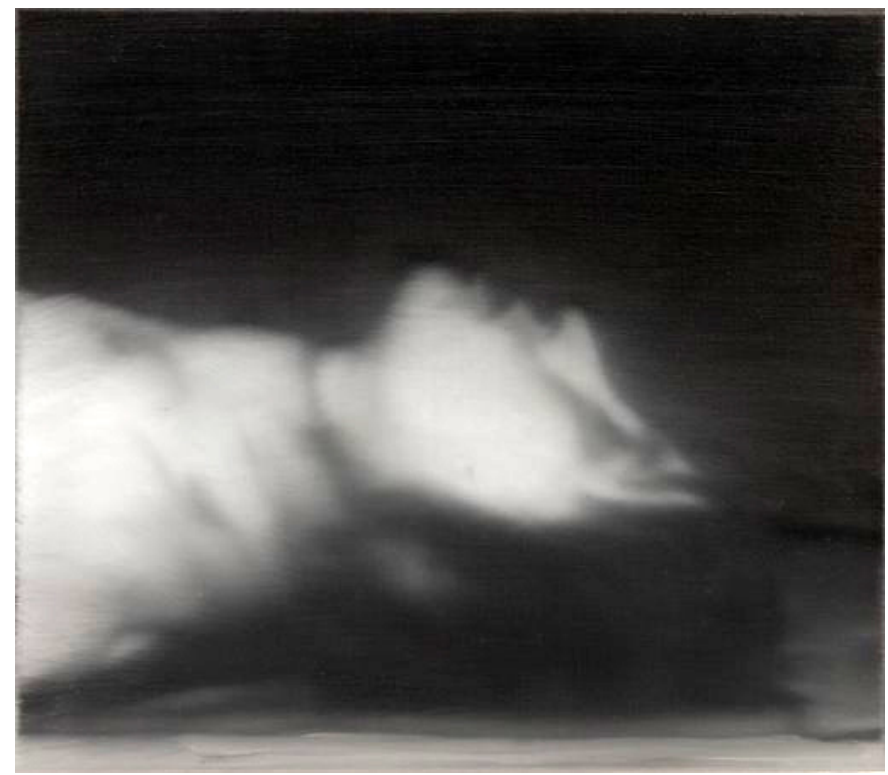

Picture 3. Gerhard Richter, Tote (Dead), from the series 18 Oktober 1977, 1988, 35 $\mathrm{x} 40 \mathrm{~cm}$

Source: https://www.gerhard-richter.com/en/art/paintings/photo-paintings/baader-meinhof-56/ dead-7689/?\&categoryid=56\&p=1\&sp=32 [access: 22.11 .2020 ]. 
tioning the suicides in Stammheim. Therefore, he realized that the image would be perceived as a provocation, therefore its self-definition in terms of kitsch can be perceived in two ways: as an ironic and distanced strategy, or as a calculated and safeguarding strategy.

Eleven years after the death of the RAF leaders in Stammheim, a series of paintings devoted to these events was published by the most respected German painter in the art world. As part of the October 18, 1977 (1988) series, Gerhard Richter painted fifteen canvases based on press and police photographs illustrating prison life, death and terrorist burials. Richter considers the first generation of the RAF as victims of their own ideology, "but not the victims of any specific ideology of the left or of the right, but of the ideological posture as such. This has to do with an everlasting human dilemma, in general: to make a revolution and to fail...”3

Leith Passmore noted, that "Richter broke through the "amnesia" or "taboo" surrounding the RAF, where the amnesia is understood not as an absence, but a dominant narrative. The story "locked in place" by the photographs of the dead RAF terrorists in the immediate aftermath of their deaths was bound up with the official explanation of what happened that night in October 1977: the images of the dead terrorists in particular were produced by prison officials and published as part of the state version of events. By piercing the assumed reality of the photographs - breaking the connection between the image and real - Richter laid bare their subjectivity and opened them up for "re-coding” or "multiple instruction." It must be noted that those writing of amnesia, repression, and taboo at the time, were also those who championed an alternative "coding" of the suicide photographs."

In his interpretation of the 18 Oktober 1977 series, Benjamin Buchloh emphasized that "Richter's photopaintings have consistently opposed the universal presence of $[\ldots]$ gaze and its ubiquitous instrumentalization of the look. This has particular importance within the group October 18, 1977 in relation to a gaze that, in the police-commissioned press photographs that served Richter as a point of departure, seems ritualistically to assure itself of the final liquidation of the enemies of the state. But at the same time this group resists the modernist restriction of painting to a mediation of historical experience exclusively in the discursive reflection on the evolution, the materials, and the procedures of the pictorial medium itself. It is in the construction of this dilemma, marked by both the conflict in medium-painting/photography-and the conflict in ideas about representability - the painting's self-referenciality/photography's "transparency" to the event-that Rich-

${ }^{3}$ Quot after: K. Theweleit, Comments on the Ghost of the RAF, https://www.pismowidok. org/en/archive/2013/2-images-of-terror-visibility-of-history/comments-on-the-ghost-of-the-raf [access: 22.11.2020].

${ }^{4}$ L. Passmore, Another New Illustrated History: The visual turns in the memory of West German terrorism, "EDGE - A. Graduate Journal for German and Scandinavian Studies" 2009, no. 1(1), article 2, p. 5, https://scholarworks.umass.edu/cgi/viewcontent.cgi?referer $=\&$ httpsredir $=1 \&$ article=1004\&context=edge [access: 22.11 .2020 ]. 
ter's work testifies to the contemporary difficulties in the production of historical representation in painting." 5

It so happened that the "collective repression" of the memory of the RAF, initiated by the German state, was also counter-effective. Political censorship has created a climate of resistance that favors the propagation of alternative versions of deaths in Stammheim, which echoes clearly in Buchloh's essay.

Almost every ideologically motivated attempt to change the world ended in violence. Some carried the burden of its abuse, others - of being its victims. In this situation, it is not possible to blame the ignorance of those who saw in the artists a nostalgic desire to erect monuments to terrorists. Thus, the exhortation of the visual arts for a polyphony of meanings in a crisis of communal identity can be seen in two ways: as a historically unfortunate moment or, quite the contrary, as an opportunity to "put a shoe in a slamming door." Why would artists hesitate to actively take advantage of this particularly sensitive (and perhaps unique) moment of social satiation with ideologies and violence to try to create new visions of the citizen. To this end, art tactically penetrated the visual archives to disrupt the one-dimensional official iconography of the German Autumn.

Back in the 80's, when Margaret Thatcher was trying to silence the TV so that it would not become a "voice" for the Irish Republican Army, TV broadcasters found very creative ways of circumventing her prohibitions. For example, Gerry Adams (one of the leaders of the IRA) continued to appear on TV cameras, but was dubbed by a famous actor, Steven Rea. In artistic space, the so-called Troubles (i.e. the 30-year conflict between IRA volunteers and the British army, the police and the Protestant paramilitary groups during the late 20th century) were most expressively reflected on three planes: on murals, in the cinema and in visual arts.

Interestingly, artistic involvement and expression took on a completely different character on each of the planes: mural artists expressed their willingness to prolong the conflict and thus reinforced social polarization; film directors adopted a slightly more diverse position (sympathizing with the republicans rather than loyalists); and visual artists seemed to choose the third way in this bipolar conflict.

In August 1998, the Real IRA carried out one of the biggest bomb attacks of the Troubles period in the town of Omagh. 29 people were killed then and over 220 were injured. It was the bloodiest expression of republican dissenters' disapproval of the Good Friday agreement. At the site of the explosion in 2008, an artist, Sean Hillen, together with a landscape architect, Desmond Fitzgerald, placed a 6-ton glass obelisk with a shimmering heart emblem inside. It is only part of a much larger installation, because in the nearby Memorial Park there is a heliostat (computer-controlled mirror) directing the sun's rays to 31 smaller mirrors with the

${ }^{5}$ B. Buchloh, A Note on Gerhard Richter's October 18, 1977, “October” 48/1989, p. 93, https://scholarworks.umass.edu/cgi/viewcontent.cgi?referer=\&httpsredir=1\&article=1004\&context=edge [access: 22.11.2020]. 


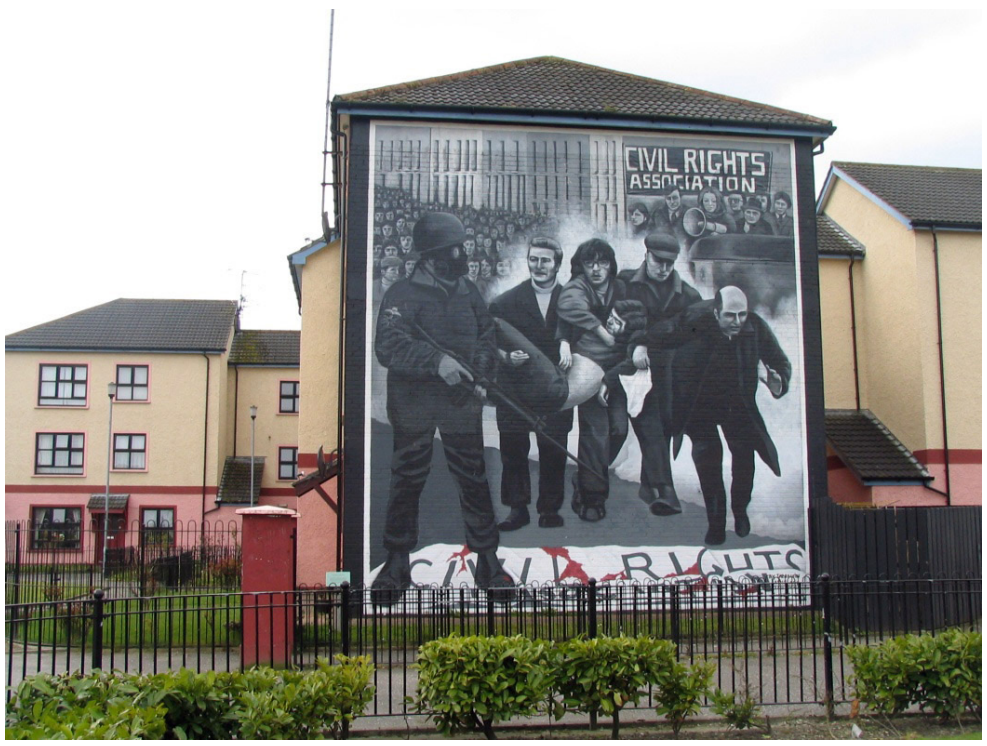

Picture 4. Derry/Londonderry, Bloody Sunday, mural by Bogside Artists

Source: https://theirishrevolution.wordpress.com/2013/07/12/the-rossville-street-derry-bloodysunday-murals/ [access: 22.11.2020].

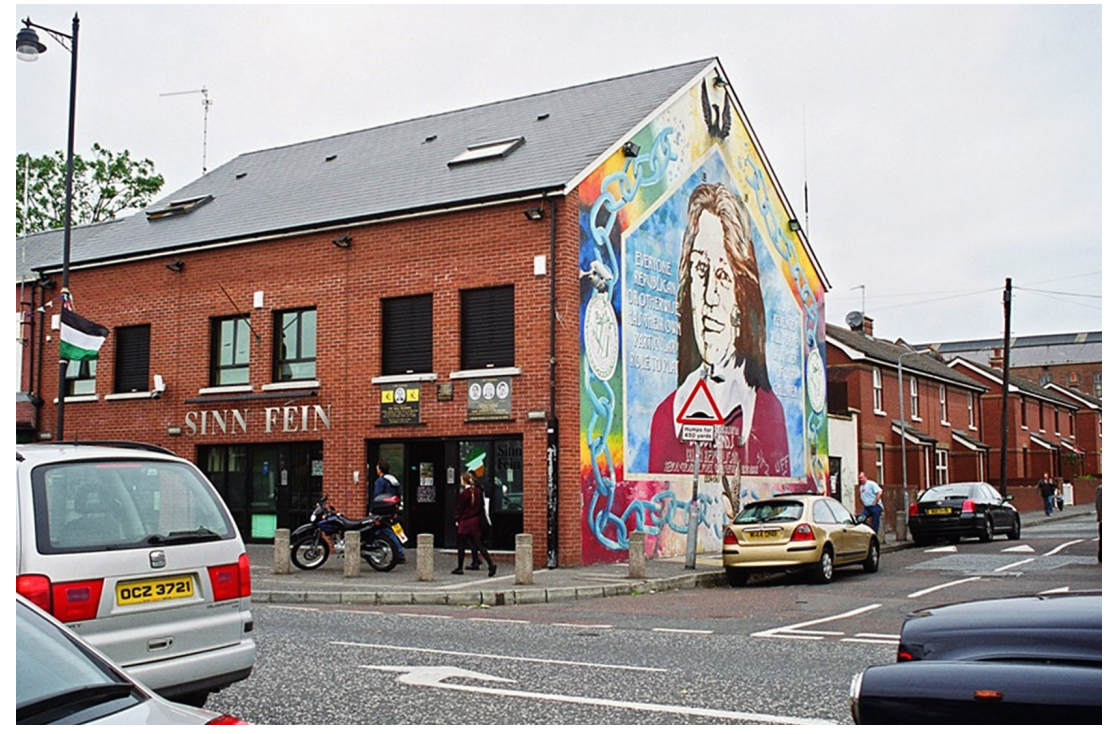

Picture 5. Belfast, Falls Road, Sinn Fein party headquarters, on the facade of the building: Bobby Sands - the first victim of the hunger strike

Photo by Jacek Zydorowicz. 

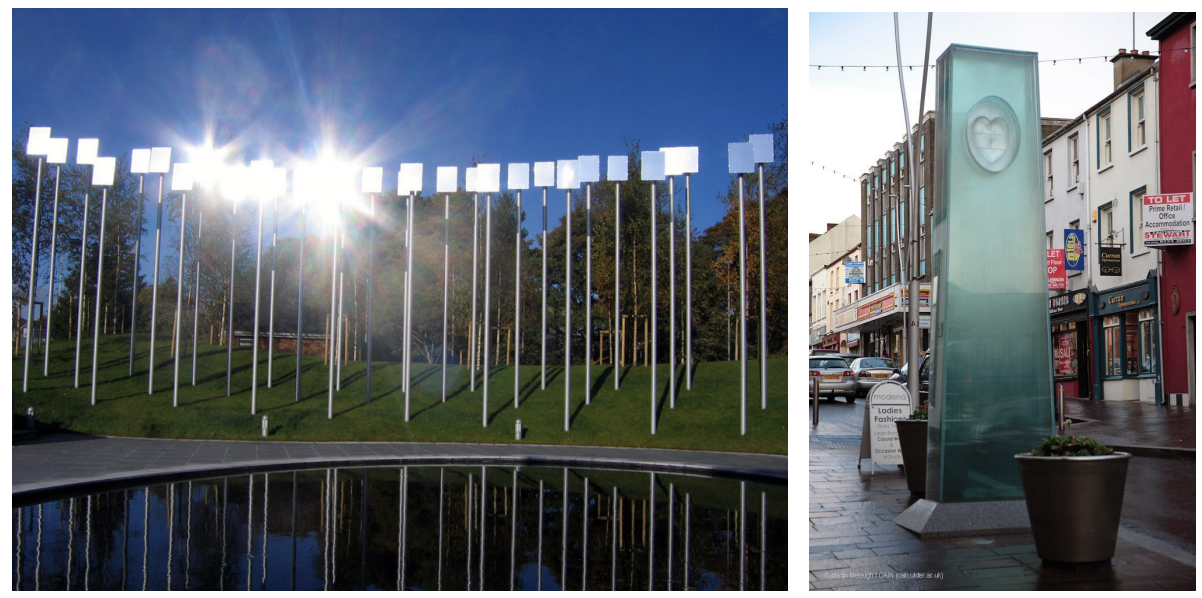

Picture 6. Sean Hillen, Desmond Fitzgerald, The Omagh Bomb Memorial „Garden of Light"

Source: https://cain.ulster.ac.uk/victims/memorials/static/photos/491.html [access: 22.11.2020]; https://www.waymarking.com/gallery/image. aspx?f=1\&guid=5b611e8f-58e0-41a0-8257b6735773b6af\&gid=3 [22.11.2020].

names of the victims of the attack (as one of the victim's unborn twins were taken into account). The role of the mirrors is to redirect this light beam towards the glass obelisk. This is actually an exception, because in the UK it is relatively rare to commemorate acts of terrorism and their victims in this way.

Since 2006, the Arts Council of Northern Ireland (AC NI) has been steadily collecting art and documentation of current and archival exhibitions devoted to 30 years of Troubles history. Using this collection, Liam Kelly and Feargal O’Malley created an exhibition at the Ormeau Baths Gallery (Belfast, 2009). The curators openly admitted that the project did not claim to be representative of the entire collection, it was only intended to show selected artistic perspectives. One of the most striking works was the installation Surveiller (2004). Una Walker combined her artistic and academic-research competences. On transparent acrylic panels, she published tabular lists of artistic activity in Belfast during the Troubles period. Each pane corresponded to the subsequent years from 1968 to 2001. In this way, the gallery walls became a readable chart, which, apart from the chronology, allows to assess the significant differences in this activity at a glance. This work is ostentatiously cold, devoid of any elements that could evoke emotions, it confronts the viewer only with dry data: when, where, what and who. Walker spent 128 days inventorying the exhibitions, but decided to "purge" this data of any information about the content, quality, and appearance of these projects (that is, everything you'd normally expect from art commentaries). As the title suggests, 


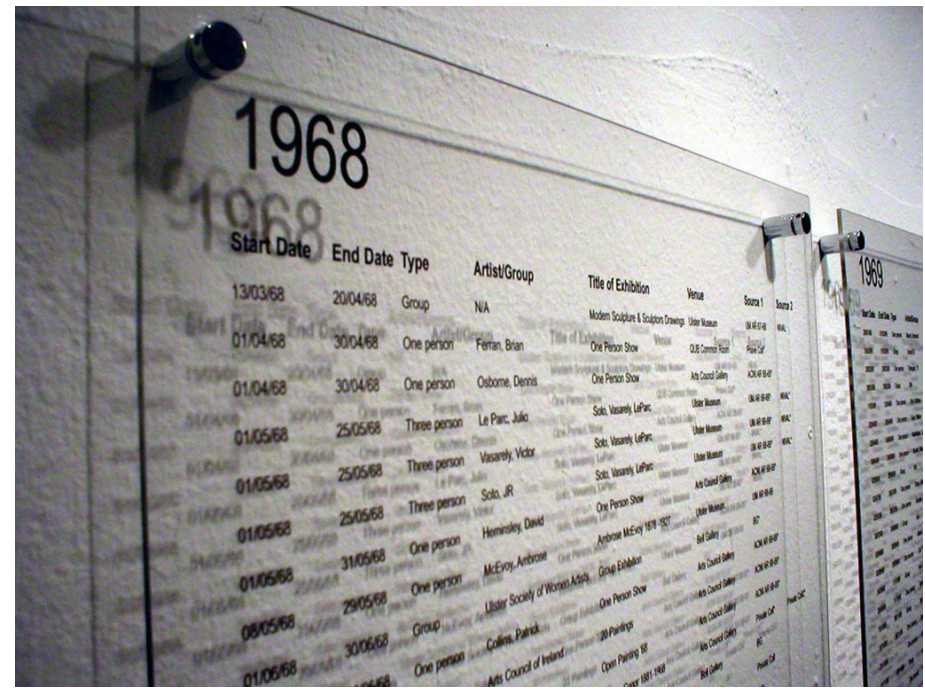

Picture 7. Una Walker, Surveiller, 2004

Source: https://www.goldenthreadgallery.co.uk/events/surveiller/?v=9b7d173b068d [access: 22.11.2020].

the recipient becomes the archives' supervisor. The recipient also has a computer at their disposal, where they can search the data themselves, but then they become surveillance objects themselves, as they are watched by a surveillance camera transmitting an image to the screen in another part of the installation. The viewer is forced to independently confront the data with historical social, economic and political conditions. So we can observe that the year 1974 was poor in terms of the so-called artistic production, as many of the then galleries were closed due to fear of bombs. Of course, the artists were not idle then, but for political reasons the institutional spaces of public communication were limited. For comparison, 1994 was much better in terms of the number of exhibition initiatives, as it is the time of signing a ceasefire between the parties to the conflict. The following years looked just as good, as the belief in the role of artistic culture as an effective catalyst for social tensions became widespread, and thus - the belief that art can contribute to economic regeneration.

In a much less “conceptual” manner, Andre Stitt referred to the Northern Irish semiotics of cruelty. In the performance Conviction (2000), with his head smeared with tar and feathers, he decided to crawl from Donegall Pass (a street in southern Belfast inhabited mainly by loyalists) to the Duke of York pub, thus covering the distance of one mile. The artist, by replicating ancient religious penitential acts and humiliating rituals of execution, remembered from his youth, wanted to deal with 


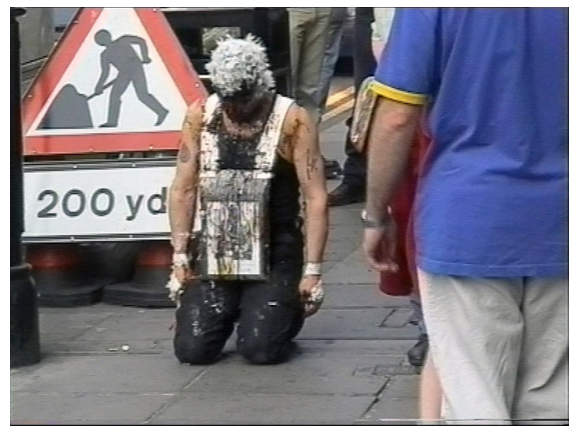

Picture 8. Andre Stitt, Conviction, performance (2000)

Source: http://www.troublesarchive.com/artforms/performance-arts/piece/conviction [access: 22.11.2020].

the personal psychogeography of Belfast. Within the Protestant community (from which he comes) women who became involved in an affair with Catholics were punished in this way. Stitt chose the path of performative activities because he was irritated by everything that politically engaged murals communicated around him and their privileged position in building local narratives. However, he was not in the least an advocate of the apolitical nature of art, but at most a moderate iconoclast. He expressed his attitude to this issue most clearly in his youth as part of the action Art Is Not A Mirror It's A Fucking Hammer (1978). He wrote the slogan on walls in various parts of Belfast, so the slogan became a mini-manifesto and his artistic stance was intended to reflect "a number of concerns regarding territory, political power and the potential for ritual as a means of empowerment and for reclaiming or transforming identity." ${ }^{6}$

The Northern Irish artistic idiom seems very difficult to universalise. The main problem is the difficulty in defining the conflict there. How should it be framed? In terms of religion, politics, rivalry between separatist (national liberation) terrorism and state terrorism, urban guerrilla warfare, fighting for human rights, asymmetric war? Art certainly does not want to provide such answers, and its value rather lies in the ability to provoke the right questions.

Similar mechanisms were triggered in the Palestinian problem. Ariella Azoulay ${ }^{7}$ (Israeli curator and researcher) noted that some kind of amnesia was programmed in the Israeli society in the face of the Nakba tragedy, the occupation and the harm

\footnotetext{
${ }^{6}$ http://www.troublesarchive.com/artforms/performance-arts/piece/art-is-not-a-mirror-itsa-fucking-hammer [access: 22.11.2020].

${ }^{7}$ A. Azoulay, Different Ways Not to Say Deportation: Unshowable Photographs, Fillip Editions, Vancouver 2012. See also: A. Azoulay, Civil Imagination: A Political Ontology of Photography, Verso Books, London-New York 2012.
} 
suffered by the Palestinians. Meanwhile, in the world, despite frequent terrorist acts, public opinion displayed a lot of understanding for their national liberation spirit, especially in the context of publicizing activities opposing the violation of human rights and occupation (illegal under international law). Of course, this does not mean that film productions or exhibitions of pro-Palestinian art were held without controversy.

In 2005, the DePaul University Museum (Chicago, Illinois) hosted a collective exhibition of sixteen Palestinian artists entitled The Subject of Palestine. According to the assumptions of the curator Samia Halaby and the Students for Justice in Palestine organization, the project was to show the complex, tense social situation in the face of identity threats, and to juxtapose the works of Palestinian artists living in the Gaza Strip and the West Bank with the art of the diaspora. The methods of artistic communication sometimes differ depending on where the artist lives and for whom he creates. Locally, there is a need for clear messages for the national liberation-minded audience, the symbolism of which is not always clear to the Western audience. On the other hand, Palestinian artists educated in American and European art academies are perfectly able to fit into our aesthetic expectations and interpretive habits - they build their visual metaphors by creating installations, video art, etc.

For a more complete picture of the attitudes of American galleries and museums towards Palestinian art, it is also worth mentioning the exhibition Made in Palestine. Curator James Harithas spent months preparing for it, traveling around the Middle East with Samia Halaby, meeting artists and selecting works. Eventually, twenty-three artists - both from Gaza and the West Bank as well as from the diaspora - were invited to participate. The first opening took place at the Station Museum in Huston (2003) and was a huge success. The exhibition was planned for three months, but due to the scale of interest, it was extended by another three, and this was certainly not only due to the quite substantial Palestinian community there. The curator therefore felt the imperative to organize a "tour" in the USA, but unfortunately received over ninety refusals from museums and galleries. In one of the interviews, Harithas lamented: "I thought I had enough contacts to get this exhibit shown in museums across the nation, but I found out that even people who I considered close contacts said off-the-record they would lose their museum funding if they were to hold an exhibit that was pro-Palestinian." ${ }^{8}$ Samia Halaby received similar answers when looking for a place in New York. ${ }^{9}$ After the attacks of September 11, 2001, for many, such a project was equal not only to the promotion of anti-Semitic attitudes, but also to attempts to justify terrorism.

${ }^{8}$ O. Roychoudhuri, Made in Palestine, www.motherjones.com/arts/feature/2005/05/palestinian_art.html [access: 22.11.2020].

${ }^{9}$ R. Kanazi, The Art of Politics, http://www.worldpress.org/Americas/2280.cfm [access: 22.11.2020]. 


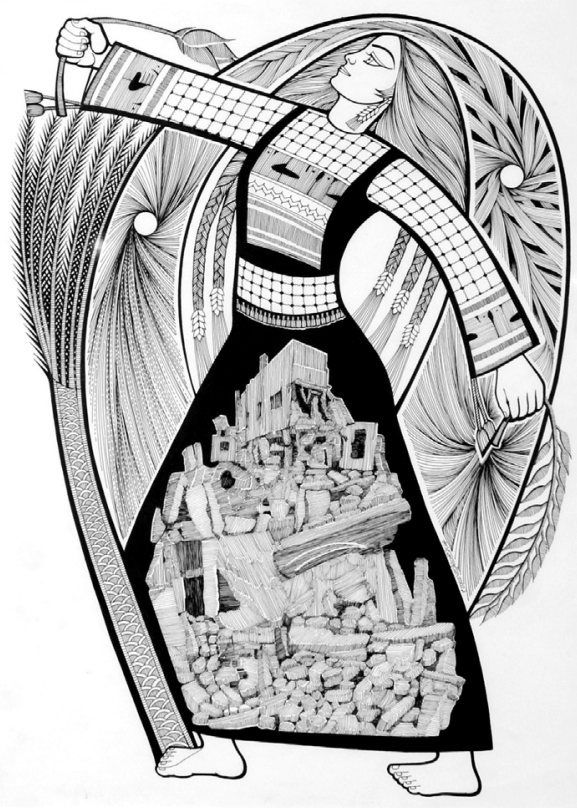

Picture 9. Abdel Rahmen Al Muzayen, Jenin, 2002

Source: http://www.prweb.com/releases/2006/02/prweb348579.htm [access: 22.11.2020].

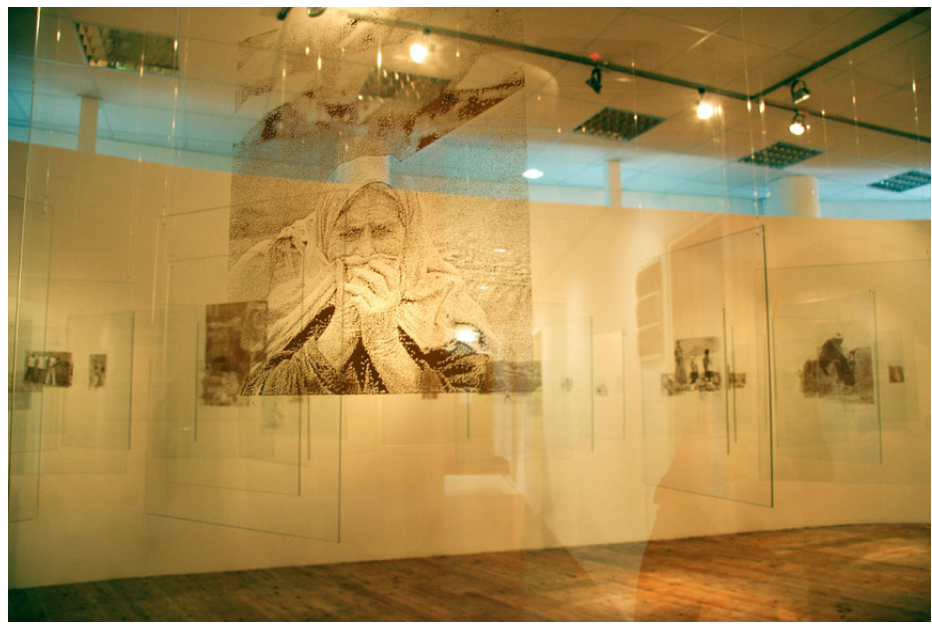

Picture 10. Rana Bishara Blindfolded History (2002-2012)

Source: https://www.artsy.net/article/artasiapacific-the-art-of-resistance-interview-with-rana [access: 22.11.2020]. 
In her piece Blindfolded History, Rana Bishara decided to create a peculiar chronicle of the occupation by printing her photographic images on glass with chocolate. In this way, the semi-transparent panes gave the effect of interpenetrating the images, and the specific play of light and the subject matter made the chocolate look like dried blood. As the artist recalls: "The many scenes I remembered as a child and seen as an adult, of soldiers killing, abusing and torturing women and children, disgusted me and made me feel the urge to record history in a civilized, creative way. So I decided to do something in chocolate. Unsweetened chocolate represents the fat of our body and is an ironic way of protesting against sadism, abuse and war crimes. Each sheet of glass symbolizes one year of the occupation. It has been 66 years. These critical chapters are reflected in many iconic images-a woman mourning her exile and crying, a child facing a tank. The fragile glass contains a record of visual memory and history; its ephemerality shows the urgency of the matter to be resolved." 10

As for European exhibitions, the Hague collective project No Man's Land. Contemporary Art From Palestine was organized as part of the series entitled Borders (2007). The intention of the curator Robert Kluijver was to familiarize Europeans with artistic strategies of resistance illustrating the powerlessness and limbo resulting from the occupation. All the works were in some way relativized to space, especially to the mechanisms of its control. An excellent and paradoxically humorous example is the video of the Nazarene Sharif Waked entitled Chic Point - fashion for Israeli Checkpoints (2003). Since Hamas' suicide bombings have intensified, meticulous checks at checkpoints have become the norm, accompanied by commands such as “Get on your knees!”, “Pull up your sweater!”, “Take off your jacket!”, “ID card!”. Everything to detect the shahid belt or illegal weapons. That is why Waked decided to design a special collection of clothing that, being partially transparent, will make the work of soldiers much easier, and save the suspects time and humiliation. The film is conceived as a pastiche of classic fashion shows with models on the catwalk. Thus, the martyrdom stereotype of Palestine as a place of death, persecution, intifada was broken, where the last thing that may come to someone's mind is to joke about this state of affairs. It is these "safety valves" that seem essential to trauma relief.

Since September 6, 2001, the German net artist Wolfgang Staehle has been making a synchronous projection of panoramas of Manhattan, the Benedictine Comburg Monastery and the Berlin rotating TV tower at the Postmasters Gallery in Chelsea. The images came from webcams transmitting them in real time. The artistic assumption of the project was to show panoramas of eventlessness. ${ }^{11}$ Without

${ }^{10}$ H. Morgan, The Art of Resistance: Interview with Rana Bishara, http://www.artasiapacific. com/Blog/TheArtOfResistanceInterviewWithRanaBishara [access: 22.11.2020] .

11 https://www.e-flux.com/announcements/35152/2001-an-installation-by-wolfgang-staehle/ [access: 22.11.2020]. 

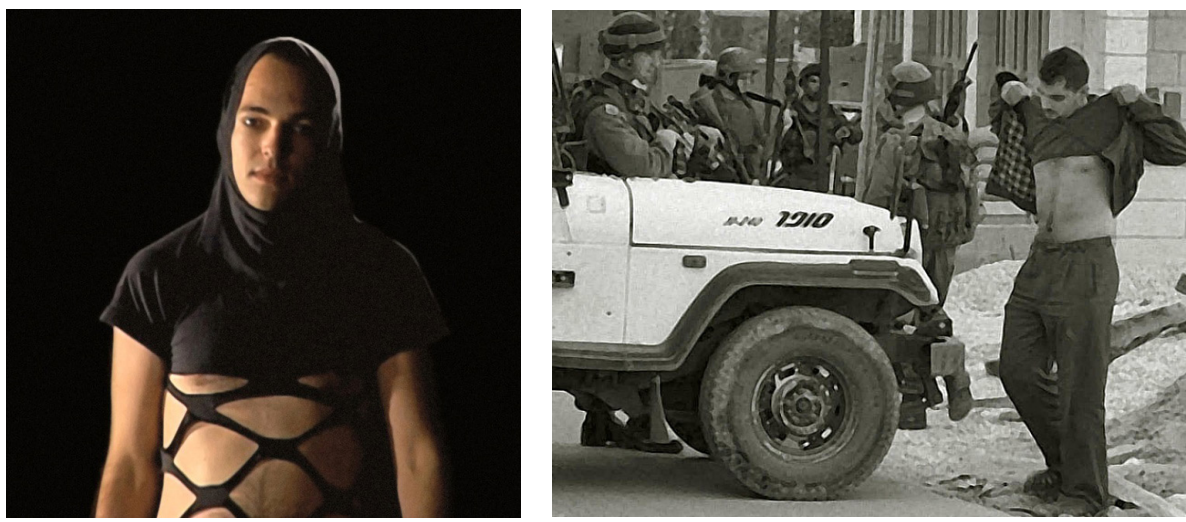

Picture 11. Sharif Waked, Chic Point: Fashion for Israeli Checkpoints, 2003

Source: https://www.ibraaz.org/publications/48 [access: 22.11.2020]; https://universes.art/en/ nafas/articles/2005/waked/sharif-waked-chic-point/waked-08 [access: 22.11.2020].

too much emphasis, we can therefore speak of the historical irony of fate, which made one of the cameras, completely against the artist's intentions, record the explosions that were considered to be the actual beginning of the 21st century. In the book The Spirit of Terrorism, Jean Baudrillard writes about the 1990s as a period of "strike events." 12 As we know perfectly well, this strike ended on September 11, 2001, when Al-Qaeda attacked the WTC towers and Pentagon.

A clear-cut boundary between "old" and "new" terrorism (and their visual representations) was created as a result of these attacks. Thanks to globalized television broadcasting (including Arabic TV channels), terrorist acts became widely known and gained a big publicity. This led to favoring islamophobia in the Western world and to anti-Occidentalism in the Arab world - exactly the model prognosticated by Samuel Huntington in his book Clash of Civilizations. Demagogues and populists on both sides of the conflict eagerly adopted this rhetoric, which led to the radicalization of political moods. Meanwhile, visual artists managed to cognitively "process" the attacks of September 11 in a far more polyphonic way than politicians and the media (despite the fact that media aesthetics were often cited by artists). Certain events and global actions only added fuel to the flames, underlining the depolarizing aspirations of art, and these were, among others: leaked torture photos from Abu Ghraib (pretext for numerous artistic references), and later the deaths of Saddam Husain, Osama bin Laden and Mu'ammar al-Gaddafi. The spectrum of artistic stances was really broad here: from helplessly replicating media rhetoric and adopting naive relativism, to an insightful problematising of social discourses,

12 J. Baudrillard, Duch terroryzmu. Requiem dla Twin Towers, Sic!, Warszawa 2005, p. 5. 

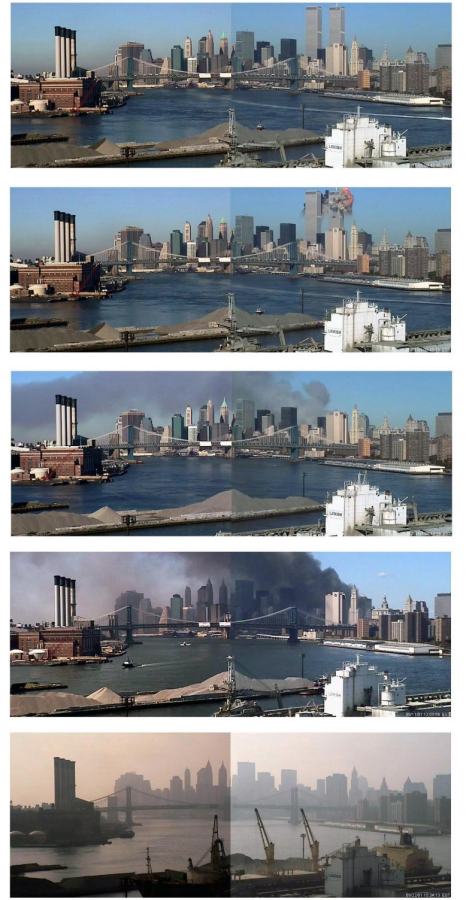

Picture 12. Wolfgang Staehle, 2001, video-stills, 2001

Source: https://staehle.wordpress.com/2010/10/03/hello-world/ [access: 22.11.2020].
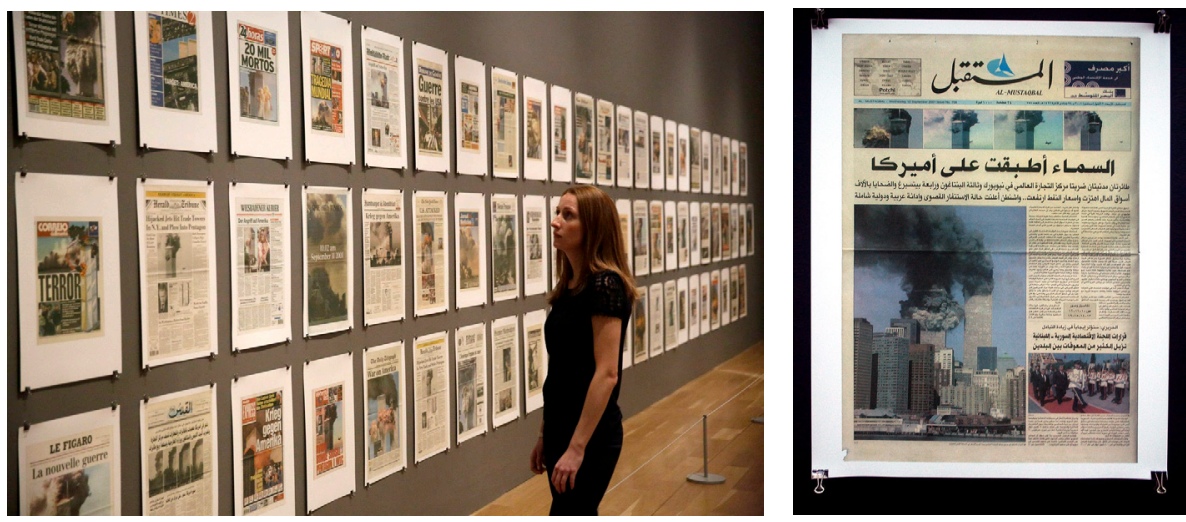

Picture 13. Hans-Peter Feldmann, 9/12 Frontpage, 2001

Source: http://www.news1130.com/2017/10/25/london-exhibition-age-of-terror-explores-artsince-9-11/ [access: 22.11.2020]; https://www.designboom.com/art/hans-peter-feldmann-atgwangju-art-biennale-2010/ [22.11.2020]. 


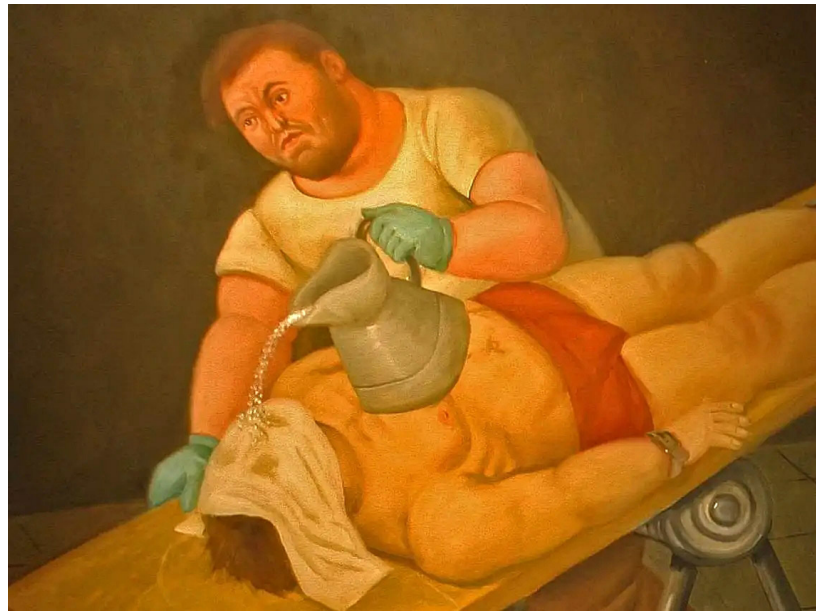

Picture 14. Fernando Botero, Abu Ghraib, 2004

Source: https://www.businessinsider.com/abu-ghraib-forsensic-examiner-on-torture-2014 -12 ? $\mathrm{r}=\mathrm{UK}$ [access: 22.11.2020].
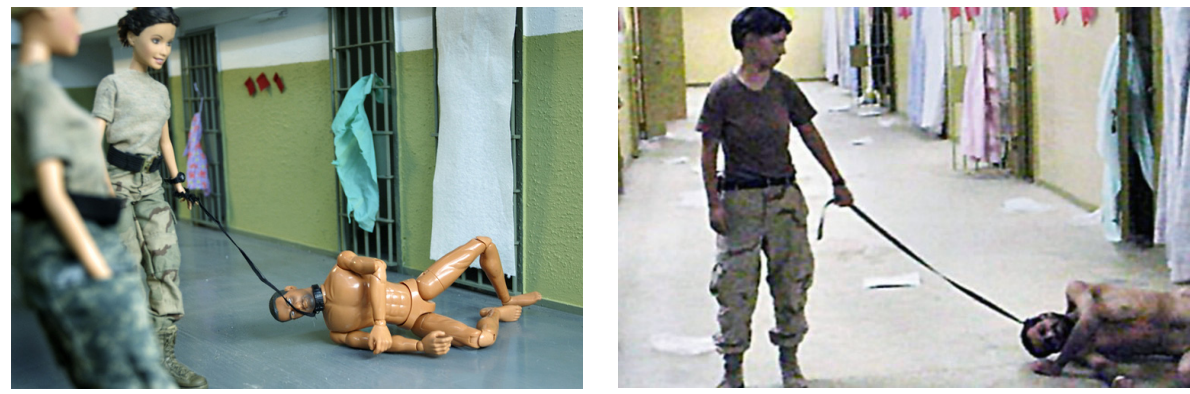

Picture 15. Billie Grace Lynn, Abu Ghraib Prison, 2006

Source: http://www.billiegracelynn.com/\#/abu-ghraib/ [access: 22.11.2020].

indicating contradictions, inconsistencies and pitfalls in the logic of the conflict in question.

As we perfectly remember, in 2004, photographs from the Abu Ghraib prison circulated in the world media, becoming an introduction to a new iconography of terror. Until then, mainly "harmless" photos and reportage film snapshots from Guantanamo Bay were known, showing Arabs in orange uniforms trapped in cages. The society then silently accepted the existence of something like "enhanced interrogation techniques.” In practice, this tactical euphemism meant extortion of 

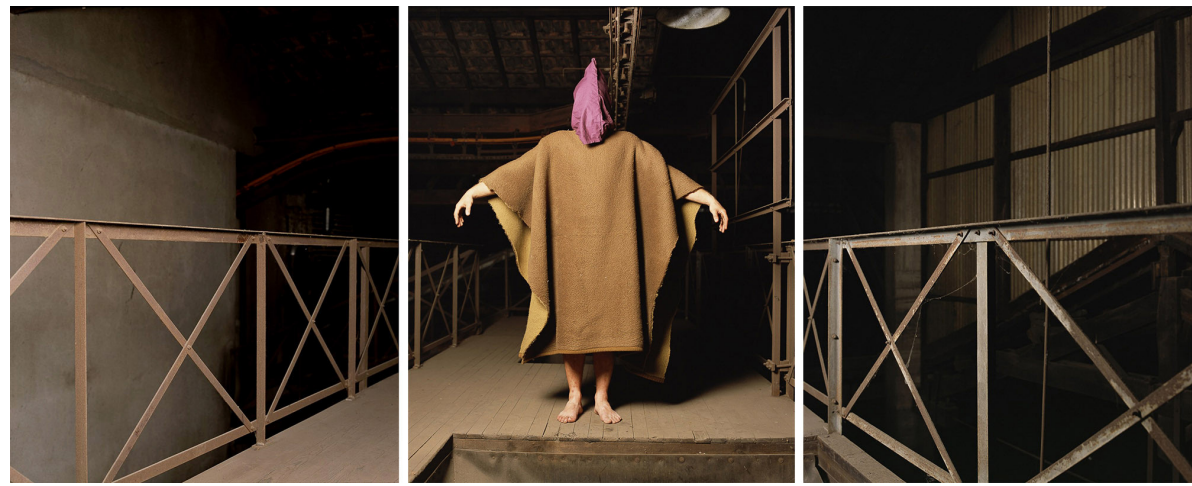

Picture 16. Andres Serrano, Untitled $X-1$, Untitled $X-2$, Untitled $X-3$, from the series Torture, 2015

Source: http://andresserrano.org/series/torture [access: 22.11.2020].

testimony by: holding in a stressful position, beating (with an emphasis on humiliating, not leaving marks), temperature manipulation (exposure to extreme cold or heat), waterboarding (consisting of immobilizing open mouth with a towel and flooding them with water, which, getting into the lungs, caused panic), threats to family and relatives, sleep deprivation, sensory bombardment (noise and bright light), sensory deprivation (prolonged isolation and cut off from stimuli), jerking, screaming, bullying (using dogs) and sexual humiliation. ${ }^{13}$

As Slavoy Žižek noticed: "The torture at Abu Ghraib was thus not simply a case of American arrogance toward a Third World people. In being submitted to the humiliating tortures, the Iraqi prisoners were effectively initiated into American culture: They got a taste of the culture's obscene underside that forms the necessary supplement to the public values of personal dignity, democracy and freedom. No won der, then, the ritualistic humiliation of Iraqi prisoners was not an isolated case but part of a widespread practice.”14

With the rise of ISIS, visual culture took on yet another face. Although the fighters of the self-proclaimed caliphate have not so far produced an iconic event on the scale of September 11, they have fully and effectively manipulated the collective imagination of both the East and the West. Among all terrorist groups it was ISIS who displayed the most professional attitude when it comes to the production and dissemination of images. Their executions and other atrocities re-

${ }^{13}$ Leave no marks. Enhanced interrogation techniques and the risk of criminality https:// phr.org/wp-content/uploads/2007/08/leave-no-marks-1.pdf [access: 22.11.2020].

${ }^{14}$ S. Žižek, What Rumsfeld Doesnt Know That He Knows About Abu Ghraib, https://inthesetimes.com/article/what-rumsfeld-doesn-know-that-he-knows-about-abu-ghraib [access: 22.11.2020]. 


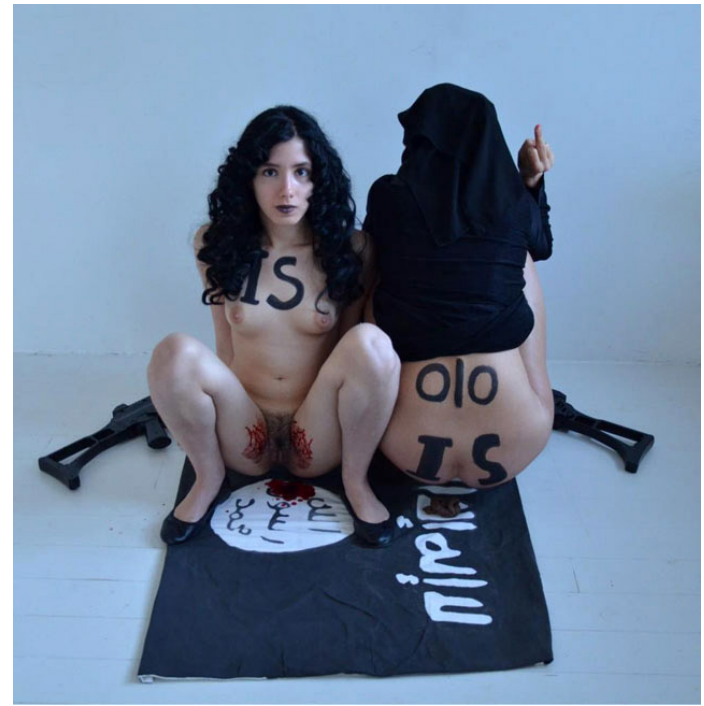

Picture 17. Aliaa Magda Elmahdy. The picture shows Egyptian feminist activist naked and menstruating on the flag of IS, while alongside her a woman dressed in a black hijab flicks off the camera and defecates on the flag too

Source: http://hyperallergic.com/145768/feminist-activists-bleed-and-shit-on-islamic-state-flagnsfw/ [access: 22.11.2020].

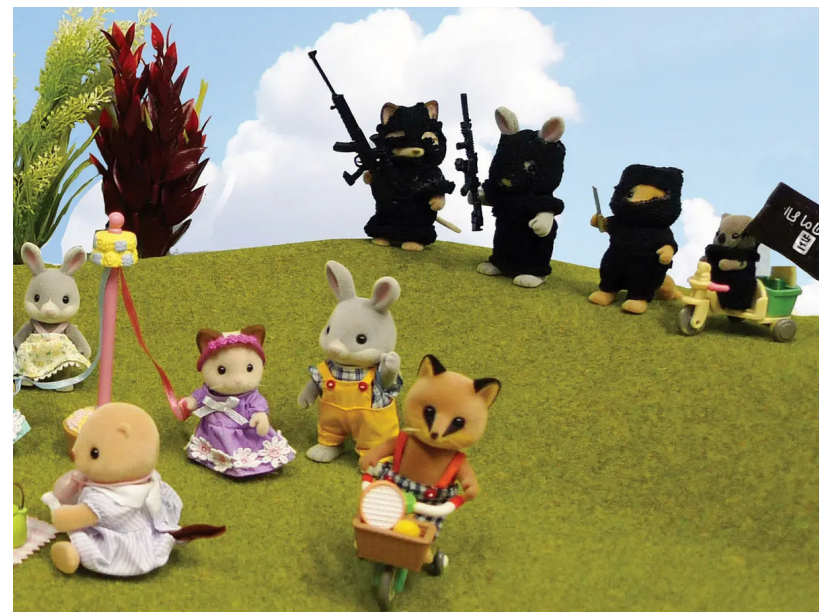

Picture 18. Mimsy, Isis Threaten Sylvania, 2015

Source: https://www.theguardian.com/artanddesign/2015/sep/26/sylvanian-families-isis-freedom-of-expression-exhibition [access: 22.11.2020] 
corded on the camera have been source material for skilfully directed propaganda films. These images, combined with attractive recruitment rhetoric, have taken over the mainstream media, and more effectively - the sphere of social media. The most prominent visual dominant of this period was the ISIS attack on the office of Charlie Hebdo, which resulted in a new incarnation of the ancient conflict between idolatry and iconoclasm. Paradoxically, Western intellectuals fell into some sort of a trap - on the one hand, they knew they were supposed to sympathize with the victims in the name of the freedom of speech (and image), but on the other hand they remained ambivalent without articulating it. The source of their ambivalence was a questionable quality of satire produced by the attacked weekly, as well as the enthusiasm for the re-reproduction of the infamous Muhammad cartoons displayed by Islamophobic groups (which only worse the angry moods following the publication of these images by the Danish daily Jyllands Posten in 2005). In this situation, it was very convenient for Western curators of art to give voice to artists from the Arab world, who seemed more legitimate to talk about ISIS. These artists managed, in a credible and graceful manner, to distance themselves from such idea of a caliphate, they even criticized it in a radical way.

In 2015, the work entitled ISIS Threaten Sylvania, London-based artist Mimsy (daughter of a Syrian exiled from Israel to Lebanon in childhood) has been removed from the Passion for Freedom exhibition at London's Mall Galleries. In fear of potential riots, the police informed the organizers that the protection of the six-day exhibition would cost as much as 36,000 pounds, which resulted in the withdrawal of the work from the exhibition. What prompted these extraordinary preventive measures? The artist, using mascots popular with children, decided to show the tensions and threats of today's terrorism. An adequate fairy tale description appeared in the exhibition catalog: "Far away, in the land of Sylvania, rabbits, foxes, hedgehogs, mice and all woodland animals have overcome their differences to live in harmonious peace and tranquility. Until Now, MICE-IS, a fundamentalist Islamic terror group, are threatening to dominate Sylvania, and annihilate every species that does not submit to their hardline version of sharia law."15

Contemporary art eagerly takes advantage of visual archives, thus filling the latest history with various forms of aesthetic, political, social and cultural speculations. Hal Foster calls it the "archival impulse" of art - and this is when artists penetrate cultural resources to gently disrupt them or to extract ambiguities in order to create alternative versions of knowledge or counter-memory. Similarly to the media, art was not always able to meet the challenges of the times. On occasions, art was even envious (though not explicitly) of the terrorists' radical stance and their performative power of changing the world and influencing human minds. That

${ }^{15}$ C. Armitstead, J. Jones, Artwork showing Sylvanian Families terrorised by Isis banned from free speech exhibition, https://www.theguardian.com/artanddesign/2015/sep/26/sylvanian-families-isis-freedom-of-expression-exhibition [access: 22.11.2020]. 
is why artists not only replicated media images of violence, but they also acted like quasi-terrorists and were able to "abduct" the imagination of their audiences. This forced recipients to go beyond their own cognitive schemas, go beyond the logic of the spectacle and come to inevitable revelations, for example the sources of conflicts, which seldom originate on one side.

Art is thus a witness - not necessarily a mimetic witness, but always a visual one - that not only reports on images and revises them, but also reflects ways of human thinking, feeling, and interpreting the reality of culture "raped" by terrorism. Art adopts many strategic approaches: visual activism, engaged art (which is often mistaken for propaganda) or critical art. One way or another, artists propose a certain kind of indeterminism: they do not so much doubt in the possibility of adequate representation of the world, but rather they make us look at how events are iconized in the media and in politics, and how these parallel discourses are created and upheld. Consequently, artists prefer ambivalence over final meanings and highlight the limitations of images created by official media and the state, which aspire to a monopoly on the production of cultural memory. This requires taking a hard and critical look on things and often adopting uncomfortable vantage points: "distance in a situation of immersion," or putting oneself in the shoes of an uprooted asylum seeker. Finally, art requires constant searching for an adequate language of expression. In this way the artworld becomes an alternative platform for the cultural memory, which is formulated on the basis of the communicative polyphony of individual utterances. As such, this space was likely to meet (and actually met) with resistance and disapproval of both the official supporters and conservative narratives. Visual arts' appeal to polyphony of meanings in the situation of the communal identity crisis can be perceived in two ways: as a historically unfortunate moment or, on the contrary, as an opportunity to proverbially "put foot in the door." The aim of art commenting on terrorism is not simply to replicate its images, as it may sometimes seem. Artistic culture possesses adequate tools to subvert rather than to put in order accepted and existing "packages" of beliefs, to expand horizons, not narrow them down.

\section{Literature}

Armitstead C., Jones J., Artwork showing Sylvanian Families terrorised by Isis banned from free speech exhibition, https://www.theguardian.com/artanddesign/2015/sep/26/ sylvanian-families-isis-freedom-of-expression-exhibition [access: 22.11.2020].

Azoulay A., Civil Imagination: A Political Ontology of Photography, Verso Books, London-New York 2012.

Azoulay A., Different Ways Not to Say Deportation: Unshowable Photographs, Fillip Editions, Vancouver 2012.

Baudrillard J., Duch terroryzmu. Requiem dla Twin Towers, Sic!, Warszawa 2005. 
Buchloh B., A Note on Gerhard Richter's October 18, 1977, “October” 48/1989, https:// scholarworks.umass.edu/cgi/viewcontent.cgi?referer=\&httpsredir=1\&article=1004\&context=edge [access: 22.11.2020].

Hannaham J., Disaster areas, https://www.villagevoice.com/2002/07/30/disaster-areas/ [access: 22.11.2020].

http://www.troublesarchive.com/artforms/performance-arts/piece/art-is-not-a-mirror-its-afucking-hammer [access: 22.11.2020].

https://www.e-flux.com/announcements/35152/2001-an-installation-by-wolfgang-staehle/ [access: 22.11.2020].

Kanazi R., The Art of Politics, http://www.worldpress.org/Americas/2280.cfm [access: 22.11.2020].

Leave no marks. Enhanced interrogation techniques and the risk of criminality https://phr. org/wp-content/uploads/2007/08/leave-no-marks-1.pdf [access: 22.11.2020].

Morgan H., The Art of Resistance: Interview with Rana Bishara, http://www.artasiapacific. com/Blog/TheArtOfResistanceInterviewWithRanaBishara [access: 22.11.2020] .

Passmore L., Another New Illustrated History: The visual turns in the memory of West German terrorism, "EDGE - A. Graduate Journal for German and Scandinavian Studies" 2009, no. 1(1), article 2, https://scholarworks.umass.edu/cgi/viewcontent.cgi?referer=\&httpsredir=1\&article=1004\&context=edge [access: 22.11 .2020$]$.

Roychoudhuri O., Made in Palestine, www.motherjones.com/arts/feature/2005/05/palestinian_art.html [access: 22.11.2020].

Theweleit K., Comments on the Ghost of the RAF, https://www.pismowidok.org/en/archive/2013/2-images-of-terror-visibility-of-history/comments-on-the-ghost-of-the-raf [access: 22.11.2020].

Žižek S., What Rumsfeld Doesnt Know That He Knows About Abu Ghraib, https://inthesetimes.com/article/what-rumsfeld-doesn-know-that-he-knows-about-abu-ghraib [access: 22.11.2020].

Zydorowicz J., Kultura wizualna $w$ dobie terroryzmu, Wydawnictwo Naukowe Wydziału Nauk Społecznych UAM, Poznań 2018. 